\title{
Examining the Relationship between the Co-Creation and Co-Innovation Success in Tourism and Hotel Industry
}

\author{
Marwa Fawzy Abdelwarith \\ Associate Professor - Tourism Studies Department \\ Sadat City University
}

\author{
Rania Hafez Mahmoud Gharib \\ Associate Professor- Hotels Studies Department \\ Sadat City University
}

\section{1- Introduction}

In the twenty-first century the organization is shifting from firm level to consumer level (Kumar and Petersen, 2013). As a result, the interaction between customers and suppliers is more important than the product they buy (Vandenbosch and Dawar, 2002).

Accordingly, communications technology has evolved to cope with the interaction between customers and companies in business (Hagel and Armstrong, 1997; Rheingold, 2000; Prahalad and Ramaswamy, 2004a, b; Prahalad and Krishnan, 2008). These trends have directed to progressively more informed customers, and have provided the opportunity for the new type of innovation, co-creation, that customer and company participated in a value co-creation and exchanged with the customers. Marketers have changed their policies by focusing on product features to focus on customer benefits. This is because customers demand unique products and services that distinguish them from other customers (Joshi and Sharma, 2004). Tourism industries businesses attempt to attract potential customers, so tourism organizations will interact with their customers to discover and realize their needs and thus provide tourism activity with distinct products and 
services and co-creation value (Shaw et al., 2011). Value creation is the value of using a product or service. At the same time, value cocreation is the communication between companies and customers. This interaction acts as the connection between stakeholders and consumers (Grönroos and Voima, 2013).

Value co-creation confirms the collaboration with customers and the collaboration with partners to innovate new service and improve customer value (Aarikka-Stenroos and Jaakkola, 2012)

In the hospitality and tourism industry value co-creation has been studied. These studies have explained the evaluation of co-creation processes with guests for the hotel industry (Shaw et al., 2011) and examined the effect of the organization's efforts to co-create values with customers and the consecutive performance progress for tourism services (Grissemann and Stokburger-Sauer, 2012). On the other hand, a few tourism studies have clearly explored co-creation in a business-tobusiness (B2B) context. Consequently, there is an urgent need to design and evolve an integrated research framework on co-creation value to achieve a better perception for companies to co-create value with their partners in the tourism field (Chen et al., 2017).

Furthermore, in recent years innovation management in the hospitality and tourism field has obtained significance where categories of tourism innovation and vital determinants of innovation were recognized (Hjalager, 2010). Williams and Shaw (2011) indicated that innovation and internationalization are important issues in the tourism industry. Nieves and Segarra-Ciprés (2015) recommended that the organizational structure of the hotel influences the development of management innovation.
However, collaboration and co-creation between a firm and its partners affect service innovation and creativity of service which discover more innovative service offerings that may develop through tourism businesses (Chen et al., 2017).

The co-creation process have been examined under the abbreviation of DART as the four key elements: dialogue (D), explaining the interaction between the organization and the consumer; access (A), referring to the information and tools that assist co-creation; risk assessment $(\mathrm{R})$, referring to the duties and rights of the organization and the customer; and transparency $(\mathrm{T})$, referring to the honesty of information between organization and customers (Prahalad and Ramaswamy, 2004b).

This paper aims to examine the relationship between co-creation and co-innovation in the success of the tourism and hospitality industry. It also investigates the influence of customers on the co-creation and co-innovation success. Specifically, we address three research questions: (1) what is co-creation?; (2) what is co-innovation?; and (3) what is the relationship between co-creation and coinnovation in tourism industry?

\section{Literature review}

\subsection{Co -creation}

At the past times, customers buy the products and services as the suppliers produced without any intervention from them in designing or producing the products or services. Today, consumers can share with the suppliers in the idea of the products and services, designing and production (Ballantyne, 2004). Consumers and suppliers participate and cooperate to create value by modifying and co-produced products and services (Payne et al., 2008). Value co-creation is preferable for 
organizations as it make them more closer to their consumers and more aware of their needs and preferences (Payne et al., 2008; Haro et al., 2014).

Co-creation can be described as a participation and joining between the supplier and the consumer to create value where the consumer acts as an innovator (Clathoth et al., 2013; Ind and Coates, 2013; Chen et al., 2017). The "co" in Co-creation indicates to the parties in the process of value creation which includes consumer, organizations, brand communities and others (Saarijarvi and Kannan, 2013). Furthermore, "creation" refers to the consolidation and integration of several resources participated by different parties (Sjodin and Kristensson, 2012). The main purpose of co-creation is "attracting customers and stakeholders to innovate valuable experiences with each other" while promoting network economies (Ramaswamy and Gouillart, 2010).

Co-creation employ the hierarchical method of management and the linear method of innovation, therefore, stakeholders create all the possibility to influence and give significative and relevant solutions in a collaborative environment (Kirah, 2009). The result of some studies suggested that it is the value creation in a more successful process in which consumers and organizations work with each other to innovate new products and services (Skiba and Herstatt, 2009; Ind and Coates, 2013).

Value co-creation changes firms views from firm-centric to be more participated with their customers to create value for them (Albinsson et al., 2016). Co- creation is based on the concept of service-dominant logic (SDL) which modulates the relationship and the communication between the consumer and the organization (Vargo and Lusch, 2004; Lusch et al., 2008). It considers the customer as a basic element and co-creator of value instead of only receiving of value and the organization plays as a facilitator to the role of customer in co-creating value instead of solely producing value (Haro et al., 2014). In value co-creation, value is produced by the consumer during the consumption process (Johnson and Neuhofer, 2017). Co-creation happens when there is a collaboration between the organization and their customers who jointly participate in creating unique value (Prahalad \& Ramaswamy, 2004b; Prahalad \& Krishnan, 2008; Sarmah et al., 2017).

The role of customers in co-creating value is through giving suggestions, new ideas and sharing information (Auh et al., 2007, Sahi et al., 2017). Customer involvement is a main condition to co-create value. Customer participation takes place at three levels: low, moderate and high where co-creation occurs and the customer becomes more controllable to the service he delivered (Bitner et al., 2000; Sarmah et al., 2017; Sahi et al., 2017).

Ramaswamy and Gouillart (2010) proposed that there are four factors for co-creation: experience approach, the collective intelligence, platform of engagement, and network relationships. A customer, who is knowledgeable, intelligent and engaging in working with firms to create value, for him and for the public, this includes social issues of ethics and the environment. For example, the production and design of green IT, greening by IT and sustainable products are the outcome of co-creation processes with customer communities (Sang et al., 2012).

Co-creation is an interactive processes between the performance of the organization and its current and potential customers (RussoSpena and Mele, 2012; Pilleret et al., 2010; Nicolajsen and Scupola, 2011). Firm 
Performance is the ability of the firm to reach sustained competitive advantages as supported by resources that are useful, and scarce, which cannot be replaced by strategic alternatives (Tijmes, 2010). The value co-creation is a vital goal as it can support firms in achieving the consumer's needs and in developing the process that satisfies the desires and needs of customers (Lusch et al., 2008).

Furthermore, Information and communication technology is necessary for value co-creation as it reinforce the relationship between customer and the firm and facilitate the participation of customers with the organization in designing and delivery of new services and products (Della Corte et al., 2009; Reay \& Seddighi, 2012; Chen et al., 2017). As a result service providers should be cared to enhance their business information technology to increase the efficiency of cocreation activities (Chen et al., 2017). Cocreation offers strategic opportunities for creating value. Providers suggested that there are three important types of value co-creation opportunities: Technological opportunities such as (digital TV, broadband, and third generation mobile services), opportunities that supported by the development of the industry as new channels for customer promotion and opportunities supported by customer preferences and lifestyles that depend on their learning and knowledge of the customer, for example, the trend towards uniqueness and excellence for customers (Lewis and Bridger 2001; Windham and Orton 2001). This trend proposes consumers will wish to co-create more unique, experiential and distinguished goods and services. Red Letter Days is one of many firms gaining from customer experimentation. It is a UK company providing tailored, extreme experiences. This trend also assists providers with a growing opportunity to use marketing and promotion for individualized and distinguished products (Payne et al., 2008). Also, when firms emphasize the marketing interactions the more communication with customers, the more firm know about customers' preferences and needs, the better firms provide exactly what customers want and the more difficult for a competitor to take away those customers (Zhang\& Chen, 2008). Nevertheless, in a cocreating process of value creation, the business works in collaboration with all the stakeholders, and the customers. Customers identify the changes of products and services to create new value.

Co-creation activities have several advantages for the firm such as improving productlservice quality (Fuller et al., 2009; Haro et al., 2014), reducing risk especially when developing new product (Maklan et al., 2008; Sarmah et al., 2017); increase productivity and revenue and reduce costs (Ramaswamy \& Gouillart, 2010) and wider product acceptance in the market (Prahalad \& Ramassamy, 2004b). On the other hand, customers participation in value cocreation stabilizes the relationship between the customer and the organization and increase their trust in it (Vargo and Lusch, 2004; Sahi et al., 2017).

\subsection{Co-innovation}

Due to the continuous changing in the business environment, innovation becomes a necessary and important activity for any organization to survive, achieve competitive advantage and succeed in the market (Johannessen et al., 2001; Pikkemaat and Zeher, 2016). Additionally, as consumers needs and preferences change, innovation is crucial for organizations to offer innovative services and products to satisfy their needs (Ottenbacher et al., 2006). Amabile (1997) and Rigolizzo and Amabile (2015) defined innovation as the development of creative ideas that lead to 
positive results and advancement (Ehlen et al., 2017). Innovation is described as an activity mainly based on the contribution of customers to choose and create their new services and products (Sarmah et al., 2017). Hamidi and Gharneh (2017) described innovation capability as a process that enterprises acquire, integrate and handle knowledge to generate creative ideas and new products and services to satisfy customers. There is no doubt that innovation, products and processes are the key elements of value creation, but co-creation need to recognize individual experience environments (Prahalad and Ramaswamy, 2004b).

As the importance of innovation increases and becomes a fundamental tool for most service organizations, it attracts the attention theoretically and practically (Toivonen and Tuominen, 2009). For tourism and hospitality industry, service innovation is a key element which helps hotels and tourism firms to achieve competitive advantage (Hjalager, 2010) because innovative services result in attracting new clients, increasing consumer loyalty, raising sales and profitability (Nicolau and Santa-Maria, 2013; Tang et al., 2015). Also, service innovation has other positive effects for hotels and tourism firms such as reducing costs, improving service quality and value for consumers (O'Cass and Sok, 2013; Tang et al., 2015). Service innovation helps hotels and tourism firms to be more closer to their clients and more collaborative with them which result in satisfying their needs through offering new unique services and values customized for their clients (Tang et al., 2015). The cornerstone for any business is the consumer who plays a positive role in the innovation process to create value (Edvardsson et al., 2011). In other words, consumer is the main source of information to implement the innovation process. Without consumer information, the innovation process cannot succeed (Piller et al., 2010). Not all customers have the desire to involve in the innovation process so, organizations implement the innovation process with customers who have the desire to innovate and use their knowledge suggestions and ideas to develop new products and services (Haro et al., 2014).

Innovations increase progressively from the interactions between tourists, staff, and partners. For example, new thoughts are examined early and directly on the market (Toivonen et al., 2007) to monitor the reactions and opinions resulting from them and are worth continuing to work on them or need to change. Therefore, new products, services, and experiences are results of co-design and co-innovation (Hall \& Williams, 2008). Innovation is creating demand by providing the appropriate type of products and services. Such a view represents destination branding that used as a tool that focuses on the identity of the destination and the interactive processes of co-creation and co-innovation (Jernsand, 2017). Furthermore, the communication technology improvement is a key tool to implement the innovation process which helps to reduce effort and cost (Von Hippel, 2005). Also, it helps to open more access and knowledge sharing with customers which, result in their involvement in the innovation process (Nambisan \& Nambisan, 2009; Lee et al., 2012).

The main component of innovation is to provide persuasive experience with network effects for value creation. Consequently, coinnovation is a policy where new thoughts or approaches from various internal and external sources are adopted in a different way to generate new value or experience for consumers and stakeholders (Von Hippel et $a l ., 2011)$. The basis of co-innovation contains 
engagement, experience, and co-creation for a value that is complicated to simulate by competition.

The innovation policy is based on a set of principles: convergent ideas, collaboration, and co-creation of experience with partners. Innovation in the business of the organization goes through four stages. These four stages are the closed innovation, collaborative innovation, and open-innovation, and now what we call "co-innovation." Innovation is vital in light of competition in the global market. The purpose of innovation is creating value for the firm and its partner (Gupta and Govindarajan, 2003). An organization that is interested in achieving its objectives only without paying attention to the share value with the partners, it will not continue in the business long. Any organization whether a business organization, a non-profit organization or a government agency has five areas in which to create value in value chains. The co-innovation in an organization can build value, throughout those five value creating avenues, based on creativity, collaboration, and control with partners and stakeholders (providers, partner organizations, outside collaborators, consumers, and the general public) (Sang et al., 2012). Accordingly, innovation consists of three elements:

\subsubsection{Creativity}

Creativity means a process of integration of available resources, whether tangible or intangible into the innovation process. Consequently, firms could profit from the "collective creativity" of consumers from all over the world and maximize profitability (Helms et al., 2012). The co-creation enhances the changes in the environment of the value creation model by increasing consumer empowerment through the network of collaboration and consumer creativity in societies (Vargo and Lusch, 2004).

\subsubsection{Collaboration}

Co-creation is explained as collaborative business between a customer and an organization in an innovation process, where the customer and the organization collaborate in the activity of co-innovation, and cocreation of new products or services (Prahalad and Ramaswamy, 2004c; Russo-Spena and Mele, 2012). In international markets, academics suggested that collaboration with stakeholders and competitors is considered as a pattern to maintain competitive advantage (Gulati et al., 2000). In recent times, collaboration with customers as a basis of product prosperity is discussed. The World Wide Web has provided an opportunity for knowledge exchange and greater collaboration for innovation. Currently, collaborations are not limited to only between organizations but with any structure like universities, research institutes, scientific forums, and individuals. Thus, Chesbrough (2003) proposed the term open innovation to create a value for the product through internal and external innovative collaborative efforts. Moreover, the main idea of open-innovation is to create value chain throughout a new innovation environment where various complements can be combined into consequential value-creating solutions seamlessly on collaborative steps. The main feature of collaboration for cocreation is a common purpose, for making revenue, mutual experience, acknowledgment, or for entertainment only. Collaboration is particularly valuable for creation through new products, services, process innovation, and new business patterns (Sang et al., 2012). Collaborative organizations are "jointly innovative and effective, Synchronous and expandable" (Adler et al., 2011). They are 
concerned with the production of knowledge through internal and external cooperation and collaboration. To assist in external collaboration, it is vital that the organization has an internal collaborative environment. The co-innovation of product and service require a complex combination of internal and external collaborations (Sang et al., 2012).

\subsubsection{Control}

The co-creation of the organization should be managed by operational capabilities; there are some offers to customers while there are other offers that need customers. Other offers carry more costs when customized. Owners and managers are improved self-esteem (including of control, maturity and ability to choose) and more customization (Wind \& Rangaswamy, 2001).

\subsection{The relationship between Co-Creation and Co-Innovation}

Today, service companies began to increase their care in service innovation process and induce their customers to participate in it by co-creating new services (Von Hippel, 2001; Hoyer et al., 2010; Sarmah et al., 2017). Service innovation mainly depends on the customer who creates innovative products and services (Chen et al., 2011; Chen et al., 2017). Co-creation is a collaborative effort between customers and an organization in an innovation process, as the customer and organization involved in the co-creation of new products or services, co-ideation, codesign, and co-development (Prahalad and Ramaswamy, 2004c; Fu and Lehto, 2018). In part, co-creation is a definite type of customers' contribution. Therefore positive or active customer shares with the organization his opinions and experiences through an innovation process, whose result is focused on marketing and development (Russo-Spena and
Mele, 2012). The aim of co-creation is to benefit from customers and suppliers capabilities and sharing information in the innovation process (Piller et al., 2010). The customers' capability to innovate is evolving rapidly based on the improved quality of information technology, improving access to easy-to-use components and tools for innovation, and then create the best products and service (Magnusson et al., 2003). These tools which, information-based could be run on a personal computer, and they are not expensive. As a result, innovation process by customers will continue to develop despite the continued differences in desires and needs in products (Maklan et al., 2008). Von Hippel (2005) suggested that organizations and customers could innovate for themselves; this means that innovation is a democratic process affected by co-creation. Moreover, co-creation has a positive role in the service innovation. In other words, innovation is directly related to value co-creation (Lee et al., 2012).

\section{Methodology}

\subsection{Respondents}

The target populations of this study are the employees of travel agencies (category A) and hotels staff (four and five star) in Cairo and Alexandria, in Egypt, to obtain significant data. The sample was randomly chosen. The survey was administered to 420 employees. Data collection was carried out during the period from July to November 2018. There were 398 responses received, indicating an estimated response rate of 94 percent. However, only 395 of the questionnaires were valid.

\subsection{Research Instrument}

The data collecting method of the study was questionnaire forms distributed by e-mail and online versions of the questionnaire in Arabic, 
and English using Google Form Questionnaire Application. To collect data from travel agencies and hotels, the questionnaire contained a cover letter explaining the purpose of the research. It was prepared based on Likert's five scale model. The questionnaire comprises of three sections. Section 1 is the respondents' profile. Section 2 consists of 12 inquiries to measure the Co-creation of the employees with a five-point scale ranging from extremely disagree (1) to extremely agree (5). Section 3 consists of 11 questions to measure the co- innovation with a five-point scale ranging from extremely disagree (1) to extremely agree (5). The higher score of the five-point Likert scale means the higher level of co-innovation and co-creation. A pilot study was conducted to test the questionnaire validity. It was performed on four tourism and hospitality experts. As a result, the questionnaire items were written in clear language. Subsequent to this, the wording of some items was developed for the consequent formal survey. As well as reliability analysis of item-scale was conducted with 30 members working at travel agencies and hotels. Hence Cronbach's alpha of the study measures was above 0.70 .

\subsection{Measures}

\subsubsection{Co-creation}

Co-creation was measured using revised items from Prahalad and Ramaswamy's (2004b). Four key elements for co-creation experiences, under the abbreviation of DART, have been identified; dialogue (D), access (A), risk assessment (R), and transparency (T). Based on a five-point scale extremely disagree (1) to extremely agree (5). Higher scores indicated greater levels of co-creation. The Cronbach alpha reliability for the scale in this study was 0.769

\subsubsection{Co-innovation}

In order to evaluate co-innovation, the researchers used a three-item scale developed from the literature review of the co-innovation in an organization, based on creativity, collaboration, and control with partners and stakeholders. Based on a five-point scale extremely disagree (1) to extremely agree (5). Higher scores indicated greater levels of coinnovation. The Cronbach Alpha reliability for the scale in this study was 0.704

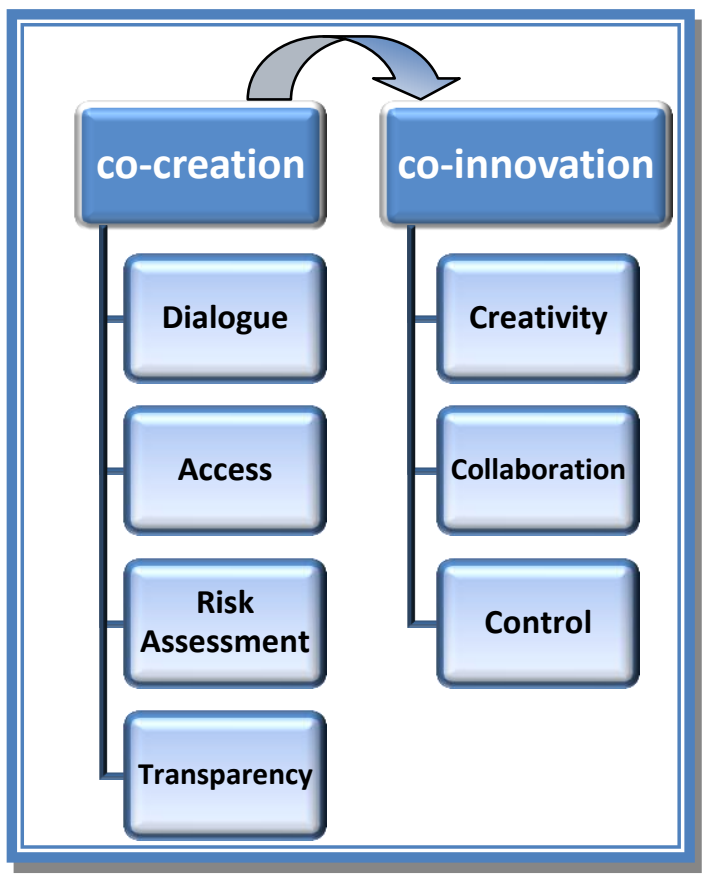

Figure (1): The relationship between co-creation on coinnovation in the tourism industry

\section{Results}

Data were analyzed by SPSS version 16 software package. The appropriate tools were used to examine the hypotheses and find reliability. Cronbach's alpha was used to test the reliability of the data, the mean and standard deviation have been calculated to categorize the sets and determine how homogenous or discrepant (inconsistent) the sample is, regarding all research variables. Factor analysis and a correlation analysis were then conducted to find out the relationship 
between co-creation and co-innovation in travel agencies and hotels. Moreover, regression analysis was conducted to measure the effect of co-creation on co-innovation.

\subsection{Respondents Profile}

The demographic profile of the respondents showed that, female respondents represent (39\%) and male (61\%). Most respondents were relatively young. About $(27.6 \%)$ of the respondents were under the age of 30 , with almost half of the sample $(56.5 \%)$ falling into the age category of 30 to less than 40 . In terms of work experience, $(4.6 \%)$ of the respondents had less than one year of experience. Nearly (27. 3\%) of the respondents were falling into the range from one year to less than five years. While $(25 \%)$ of the respondents have experience ranged from five to less than ten years, moreover the work experience of (29.4\%) of the sample was from ten years to less than 15 years. The rest of the sample (13.7\%) was 15 years of experience and above. With regard to the respondents level of education, about (14.7\%) of the sample had high education. Almost three-fourths (75.9\%) received postgraduate education, and $9.4 \%$ of the respondents were educated at the middle school.

In the first examination of the data, a reliability analysis was performed for measuring the reliability of the co-creation and co-innovation in order to know to what extent these items have an internal consistency. Cronbach's alpha is used and employed here for that reason. The generally agreed upon lower limit for Cronbach's alpha is 0.70 (Nunnaly, 1978). The results of the reliability analysis are presented in table (1). As the table shows, the reliability analysis gave alpha coefficients exceeding (.70) for the two constructs which are regarded as acceptable reliability coefficients and a good indication of construct reliability.

Table 1: The measuring constructs reliability

\begin{tabular}{|c|c||c||}
\hline $\mathbf{N}$ & Construct & $\begin{array}{c}\text { Cronbach's } \\
\text { Alpha }\end{array}$ \\
\hline \hline $\mathbf{1}$ & Co-creation & 0.769 \\
\hline $\mathbf{2}$ & Co-innovation & 0.704 \\
\hline
\end{tabular}

Then, descriptive statistics which incorporate the mean and standard deviation have been calculated to order the sets and find out how homogenous or discrepant the sample is, in regard to all research variables. The mean value for co-creation was ranged from 3.51 to 4.26 and the standard deviation from .5357 to 1.242. Moreover, the mean value for coinnovation was ranged from 1.9 to 4.29 and the standard deviation from 0.49 to 0.91 .

Table 2: Mean and Standard Deviation for the study variables

\begin{tabular}{|c|l|c||c|}
\hline \multicolumn{1}{|c|}{ Co-creation } & $\begin{array}{c}\text { Mea } \\
\mathrm{n}\end{array}$ & $\begin{array}{c}\text { SD } \\
.65\end{array}$ \\
\hline \hline \multicolumn{1}{|c|}{ Factor 1: Dialogue } & 4.03 & .58 \\
\hline 1 & $\begin{array}{l}\text { You are a good observer of } \\
\text { customers' emotions, and } \\
\text { have a good understanding } \\
\text { of the emotions of } \\
\text { customers around. }\end{array}$ & 3.66 & 1.11 \\
\hline \hline 2 & $\begin{array}{l}\text { Your organization focuses } \\
\text { on individual customers' } \\
\text { requirements. }\end{array}$ & 3.90 & 1.0 \\
\hline \hline & $\begin{array}{l}\text { Your customer works } \\
\text { closely alongside our } \\
\text { employee to support our } \\
\text { innovation team. }\end{array}$ & 3.78 & 1.05 \\
\hline
\end{tabular}




\begin{tabular}{|c|c|c|c|c|c|c|c|}
\hline \multirow[t]{2}{*}{4} & \multirow{2}{*}{$\begin{array}{l}\text { Your organization focuses } \\
\text { on identifying new } \\
\text { organizational practices } \\
\text { from customer experiences, } \\
\text { generating ideas on novel } \\
\text { products/services and } \\
\text { integrates available } \\
\text { services/products. }\end{array}$} & \multirow[t]{2}{*}{3.94} & \multirow[t]{2}{*}{.79} & 11 & $\begin{array}{l}\text { Your organization provides } \\
\text { information about product, } \\
\text { technologies and business } \\
\text { systems. }\end{array}$ & 3.99 & .79 \\
\hline & & & & 12 & $\begin{array}{l}\text { Transparency attracts not } \\
\text { only customers but also } \\
\text { investors and empowering } \\
\text { many of them to the } \\
\text { tourism industry. }\end{array}$ & 4.21 & .84 \\
\hline \multicolumn{2}{|c|}{ Factor 2: Access } & 4.09 & .58 & \multirow{2}{*}{\multicolumn{2}{|c|}{ Co-innovation }} & Mea & SD \\
\hline \multirow[b]{3}{*}{5} & \multirow{3}{*}{$\begin{array}{l}\text { Your organization } \\
\text { encourages customers (as } \\
\text { sources of value creation) } \\
\text { to create solutions together } \\
\text { (through online platforms/ } \\
\text { allocating room for visitors } \\
\text { to interact). }\end{array}$} & \multirow[b]{3}{*}{3.78} & \multirow[b]{3}{*}{1.0} & & & $\mathrm{n}$ & \\
\hline & & & & \multicolumn{2}{|c|}{ Factor 1: Creativity } & 4.09 & .49 \\
\hline & & & & 1 & $\begin{array}{l}\text { Your organization develops } \\
\text { new tourism products and } \\
\text { services from the ideas of } \\
\text { customers, employees and } \\
\text { competitors. }\end{array}$ & 3.82 & .81 \\
\hline 6 & $\begin{array}{l}\text { Your organization Share } \\
\text { proprietary information } \\
\text { with customers. }\end{array}$ & 3.51 & 1.12 & \multirow{2}{*}{2} & \multirow{2}{*}{$\begin{array}{l}\text { Your organization } \\
\text { improving the utilization of } \\
\text { existing tourism products } \\
\text { and services. }\end{array}$} & \multirow{2}{*}{3.91} & \multirow[t]{2}{*}{.91} \\
\hline 7 & $\begin{array}{l}\text { Staff training in customer } \\
\text { relations. }\end{array}$ & 3.99 & .84 & & & & \\
\hline \multicolumn{2}{|c|}{ Factor 3: Risk assessment } & 3.95 & .53 & \multirow{2}{*}{\multicolumn{2}{|c|}{$\begin{array}{l}\text { Your organization focus on } \\
\text { identifying new types of } \\
\text { customers and developing } \\
\text { products and services that } \\
\text { will appeal to existing the } \\
\text { future customers. }\end{array}$}} & \multirow[b]{2}{*}{3.96} & \multirow[b]{2}{*}{.91} \\
\hline \multirow[t]{2}{*}{8} & \multirow{2}{*}{$\begin{array}{l}\text { Your organization has a } \\
\text { clearly defined way to } \\
\text { manage our innovation } \\
\text { portfolio and prioritize } \\
\text { innovation efforts in our } \\
\text { organization. } \\
\end{array}$} & \multirow[t]{2}{*}{3.82} & \multirow[t]{2}{*}{1.14} & & & & \\
\hline & & & & \multirow{2}{*}{\multicolumn{2}{|c|}{$\begin{array}{l}\text { Product and service } \\
\text { innovation is vital for } \\
\text { gaining and sustaining } \\
\text { competitive advantage. }\end{array}$}} & & \\
\hline \multirow{2}{*}{9} & \multirow{2}{*}{$\begin{array}{l}\text { Employees at all level } \\
\text { have a clear understanding } \\
\text { of how ongoing } \\
\text { technology changes } \\
\text { directly relate to or impact } \\
\text { our innovation efforts. }\end{array}$} & \multirow{2}{*}{3.62} & \multirow{2}{*}{1.24} & & & 4.12 & .79 \\
\hline & & & & Fac & tor 2: Collaboration & 4.05 & .50 \\
\hline 10 & $\begin{array}{l}\text { When communicating } \\
\text { with customers, marketers } \\
\text { should focus largely on } \\
\text { risks and benefits. }\end{array}$ & 3.65 & 1.00 & 5 & $\begin{array}{l}\text { Your organization adopting } \\
\text { new technology to leverage } \\
\text { its resources and bridge } \\
\text { relationships to advance its } \\
\text { collaboration efforts. }\end{array}$ & 3.94 & .85 \\
\hline & Factor 4: Transparency & 4.26 & .66 & & & & \\
\hline
\end{tabular}




\begin{tabular}{|c|c|c|c|}
\hline 6 & $\begin{array}{l}\text { Advances in information } \\
\text { and web technologies have } \\
\text { led to the quick and easy } \\
\text { access of information that } \\
\text { businesses can use to } \\
\text { identify market } \\
\text { opportunities. }\end{array}$ & 4.09 & .85 \\
\hline 7 & $\begin{array}{l}\text { Technology adoption has } \\
\text { led to significant } \\
\text { performance improvements } \\
\text { and increased in } \\
\text { productivity. }\end{array}$ & 4.23 & .74 \\
\hline \multicolumn{2}{|r|}{ Factor 3: control } & 4.09 & .61 \\
\hline 8 & $\begin{array}{l}\text { Your organization has } \\
\text { information systems or } \\
\text { operational capability to } \\
\text { develop personalized } \\
\text { experience environments to } \\
\text { meet the needs and } \\
\text { preferences of customers. }\end{array}$ & 3.94 & .86 \\
\hline 9 & $\begin{array}{l}\text { Customer participation and } \\
\text { feedback during their stay } \\
\text { help the organization } \\
\text { receives more control over } \\
\text { the services quality. }\end{array}$ & 4.29 & .79 \\
\hline 10 & $\begin{array}{l}\text { Customer participation and } \\
\text { feedback during their stay } \\
\text { help the organization } \\
\text { receives less service failure }\end{array}$ & 4.19 & .81 \\
\hline 11 & $\begin{array}{l}\text { Our organization measures } \\
\text { the success of co-created } \\
\text { products and services } \\
\text { improved collaboration } \\
\text { among different } \\
\text { departments in the } \\
\text { organization. }\end{array}$ & 3.95 & .90 \\
\hline
\end{tabular}

From table (3) the results indicated that the employees' work experience have a significant effect on co-creation and co-innovation ,the employees whose work experience between 10 and less than 15 years have participated more in co-creation and co-innovation $(\mathrm{F}=$ $5.618,7.465, \mathrm{P}$ value $=0.000,0.000)$ as shown in table (3). As employees work experiences increase, they have more skills to deal with their customers. They have the ability to determine their customers' needs and preferences. Therefore, they can share information and collaborate with customers in designing and creating new innovative services and products which are customized to them in order to create value. Additionally, as employees work experiences increase, they can use all the methods and ways to co-create with their customers in the innovation process more efficiently and effectively.

Table 3: The Differences in Participants' co-creation and co-innovation in Relation to work experience

\begin{tabular}{|c|c|c|c|c|c|c|}
\hline $\begin{array}{c}\text { Work } \\
\text { experience }\end{array}$ & & $\mathrm{N}$ & mean & SD & $\mathrm{F}$ & $\mathrm{P}$ \\
\hline \multirow{5}{*}{$\begin{array}{l}\text { Co- } \\
\text { creation }\end{array}$} & $\begin{array}{l}\text { Less than } \\
1 \text { year }\end{array}$ & 18 & 4.611 & .501 & \multirow{5}{*}{5,618} & \multirow{5}{*}{0.000} \\
\hline & $\begin{array}{c}1 \text { to less } \\
\text { than } 5 \\
\text { years }\end{array}$ & 108 & 4.037 & 545 & & \\
\hline & $\begin{array}{l}5 \text { to less } \\
\text { than10 }\end{array}$ & 99 & 4,000 & .589 & & \\
\hline & $\begin{array}{l}\text { 10ante } \\
10 \text { to } \\
\text { less }\end{array}$ & 116 & 4.181 & .584 & & \\
\hline & $\begin{array}{l}15 \text { years } \\
\text { and } \\
\text { above }\end{array}$ & 54 & 4.333 & .475 & & \\
\hline \multirow{5}{*}{$\begin{array}{c}\text { Co- } \\
\text { innovation }\end{array}$} & $\begin{array}{c}\text { Less } \\
\text { than } 1 \\
\text { year } \\
\end{array}$ & 18 & 4,611 & 502 & \multirow{5}{*}{7,465} & \multirow{5}{*}{0.000} \\
\hline & $\begin{array}{c}1 \text { to less } \\
\text { than } 5 \\
\text { years }\end{array}$ & 108 & 4,037 & .619 & & \\
\hline & $\begin{array}{l}5 \text { to less } \\
\text { than } 10 \\
\text { years }\end{array}$ & 99 & 4,000 & .638 & & \\
\hline & $\begin{array}{l}10 \text { to less } \\
\text { than } 15 \\
\text { years } \\
\end{array}$ & 116 & 4,181 & .729 & & \\
\hline & $\begin{array}{c}15 \text { years } \\
\text { and } \\
\text { above }\end{array}$ & 54 & 4,333 & .442 & & \\
\hline
\end{tabular}

A correlation analysis was conducted to find out the relationship between co-creation and co-innovation. The results indicated (Table 4) 
that there is a positive correlation between the two variables which mean co-creation was positively correlated with co-innovation. The findings of the path analysis demonstrate that a positive relationship was found. This result is agreed with Lee et al. (2012) who showed that co-creation has a positive role in service innovation which means co-creation is directly related to co-innovation to create value. Cocreation is a collaborative effort between customers and an organization in an innovation process, as the customer and organization involve in the co-creation of new products and services, co-ideation, co-design and co-development (Prahalad and Ramaswamy, 2004c; Russo-Spena and Mele, 2012; Fu and Lehto, 2018). In other words, cocreation is a prerequisite issue in the innovation process.

Table 4: Correlations among the Study Variables

\begin{tabular}{|c|c|c|c|c|c|c|c|c|c|}
\hline$a$ & & & & & & & & & $\rightarrow$ \\
\hline$\infty$ & & & & & & & & $\rightarrow$ & $\stackrel{*}{*}$ \\
\hline$r$ & & & & & & & $\rightarrow$ & 형 & \begin{tabular}{l} 
草 \\
\multirow{0}{*}{}
\end{tabular} \\
\hline 6 & & & & & & $\rightarrow$ & $\stackrel{*}{\stackrel{*}{\rightleftarrows}}$ & $\stackrel{*}{\vec{*}}$ & స్ \\
\hline$\infty$ & & & & & 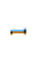 & 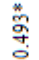 & $\begin{array}{l}\text { W. } \\
\text { m. } \\
0\end{array}$ & $\stackrel{\text { \% }}{\text { జై }}$ & 엉 \\
\hline+ & & & & $\rightarrow$ & 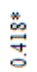 & 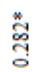 & $\begin{array}{l}\stackrel{*}{ \pm} \\
\stackrel{+}{\circ}\end{array}$ & $\begin{array}{l}\stackrel{*}{\overrightarrow{0}} \\
\stackrel{+}{0}\end{array}$ & 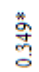 \\
\hline$m$ & & & $\rightarrow$ & 蓉 & 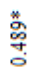 & $\begin{array}{l}\stackrel{*}{\infty} \\
\stackrel{\infty}{0}\end{array}$ & $\stackrel{\text { 오 }}{\text { : }}$ & శั & \begin{tabular}{l} 
: \\
\multirow{3}{*}{}
\end{tabular} \\
\hline 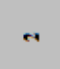 & & $\rightarrow$ & $\begin{array}{l}\text { \% } \\
\text { \% }\end{array}$ & 공 & 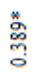 & $\stackrel{*}{\stackrel{*}{m}}$ & $\begin{array}{l}\text { Jै } \\
\text { ơ }\end{array}$ & 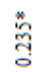 & 㠃 \\
\hline$\rightarrow$ & $\rightarrow$ & 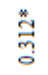 & $\stackrel{*}{\vec{D}}$ & 范 & 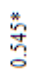 & 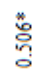 & 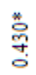 & $\stackrel{\text { }}{\underset{\sigma}{F}}$ & 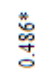 \\
\hline ". & 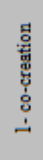 & 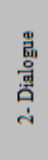 & 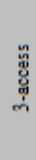 & 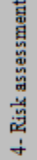 & 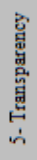 & 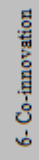 & 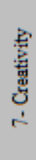 & 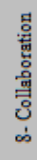 & 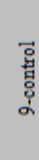 \\
\hline
\end{tabular}

* Correlation is significant at the 0.01 level
Moreover a regression analysis was conducted in order to find out what amount of total change in the dependent variable was due to the independent variable dimensions. As showed in table (5) the R2 was found to be: 0.252 which showed that $25 \%$ of co-creation was dependent on co-innovation, $\mathrm{p}<0.0005$, which is less than 0.05 , and indicates that, the regression model statistically significantly predicts the outcome variable. The regression equation as: Co-creation $=1.775+.565(\mathrm{Co}-$ innovation)

Table 5: Regression Analysis

\begin{tabular}{|c|c|c|c|c|c|}
\hline $\begin{array}{l}\text { Independe } \\
\text { nt variable }\end{array}$ & \multicolumn{5}{|c|}{ Dependent variable } \\
\hline \multirow{4}{*}{$\begin{array}{c}\text { Co- } \\
\text { innovation }\end{array}$} & \multicolumn{5}{|c|}{ Co- creation } \\
\hline & $\bar{\beta}$ & $\mathrm{T}$ & Sig & $F$ & $\mathrm{R}^{2}$ \\
\hline & $\bar{~} .56$ & 11.49 & $\overline{0.0}$ & 132.1 & 0.25 \\
\hline & 5 & 8 & 0 & 9 & 2 \\
\hline
\end{tabular}

After the data were collected and tabulated a series of statistical were tested to ensure the appropriateness of the data for factor analysis. The 32 items of co-innovation and co-creation were factor-analyzed, using principal component analysis with orthogonal VARIMAX rotation, to identify the underlying dimensions, of these factors. The exploratory factor analysis was conducted in order to gain a better understanding of the underlying structure of the data (Pitt \& Jeantrout, 1994). The results of the factor analysis, which included four factors of co-creation and three factors of co-innovation, with 32 items and explained $44 \%$ of the variance in the data with eigenvalues greater than 1.0, and factor loadings greater than 0.50 . The factor analysis 
in this study proved to be acceptably valid with the subsequent four clarifications.

First of all, the result of the correlation matrix one-tailed significance test showed that more than 50 percent of correlation coefficients were between 0.30 and 0.805, and the determinant value was 2.37 , indicating that the inter-correlations among the 32 items were strong (Noursis, 1994). Secondly, the overall significance of the correlation matrix was 0.000 with a Bartlett Test of Sphericity value of 496, suggesting that the data matrix had sufficient correlation to factor analysis. It appeared unlikely that the population correlation matrix was an identity and the use of factor analysis was considered appropriate. Thirdly, the Kaiser-Meyer-Olkin (KMO) overall measure of sampling adequacy was 0.742 , therefore the value is acceptable, which that the variable belongs together and appropriate for factor analysis. Finally, the communalities ranged from 0.60 to 0.91 with an average value above 0.65 , proposing that the variance of the original values were reasonably explained by the common factors. The results of the factor analysis created a clean factor structure with fairly higher loadings on the appropriate factors. Most variables loaded heavily on one factor and this reflected that there was minimum overlap among factors and that all factors were independently structured. The higher loadings signaled the correlations of the variables with the factors on which they were loaded.
Table 6: Factor analysis results with varimax rotation of the co-creation and co-innovation success in tourism industry

\begin{tabular}{|c|c|c|c|c|}
\hline 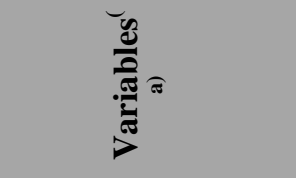 & 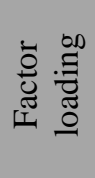 & is & 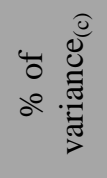 & $\underbrace{\stackrel{\tilde{\Xi}}{\Xi}}$ \\
\hline Co-creation & .632 & & 6.07 & .647 \\
\hline Factor 1:Dialogue & .614 & $\begin{array}{l}14 . \\
1\end{array}$ & $\begin{array}{l}6.87 \\
\%\end{array}$ & .762 \\
\hline 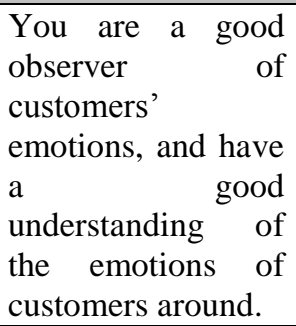 & .781 & & & .914 \\
\hline $\begin{array}{l}\text { Your organization } \\
\text { focuses } \\
\text { individual } \\
\text { customers' } \\
\text { requirements. }\end{array}$ & .622 & & & .853 \\
\hline $\begin{array}{lr}\text { Your } & \text { customer } \\
\text { works } & \text { closely } \\
\text { alongside } & \text { our } \\
\text { employee } & \text { to } \\
\text { support } & \text { our } \\
\text { innovation team. }\end{array}$ & .770 & & & .748 \\
\hline $\begin{array}{l}\text { Your organization } \\
\text { focuses on } \\
\text { identifying new } \\
\text { organizational } \\
\text { practices from } \\
\text { customer } \\
\text { experiences, } \\
\text { generating ideas on } \\
\text { novel products/services } \\
\text { pros integrates } \\
\text { and available } \\
\text { services/products. }\end{array}$ & .828 & & & .824 \\
\hline Factor 2: Access & .554 & $\begin{array}{l}2.7 \\
5\end{array}$ & $\begin{array}{l}7.68 \\
\%\end{array}$ & .740 \\
\hline $\begin{array}{l}\text { Your organization } \\
\text { encourages } \\
\text { customers (as } \\
\text { sources of value } \\
\text { creation) to create } \\
\text { solutions together } \\
\text { (through online } \\
\text { platforms/ } \\
\text { allocating room for } \\
\text { visitors to interact). }\end{array}$ & .764 & & & .824 \\
\hline $\begin{array}{l}\text { Your organization } \\
\text { Shares proprietary }\end{array}$ & .586 & & & .743 \\
\hline
\end{tabular}




\begin{tabular}{|c|c|c|c|c|}
\hline $\begin{array}{l}\text { information with } \\
\text { customers. }\end{array}$ & & & & \\
\hline $\begin{array}{l}\text { Staff training in } \\
\text { customer relations. }\end{array}$ & .810 & & & \\
\hline $\begin{array}{ll}\text { Factor 3: } & \text { Risk } \\
\text { assessment } & \end{array}$ & .529 & $\begin{array}{l}2.2 \\
4\end{array}$ & $\begin{array}{l}6.86 \\
\%\end{array}$ & .714 \\
\hline \begin{tabular}{lr}
\multicolumn{3}{c}{ Your organization } \\
has a clearly \\
defined way to \\
manage & our \\
innovation & \\
portfolio & and \\
prioritize & \\
innovation & efforts \\
in & our \\
organization. &
\end{tabular} & .669 & & & .707 \\
\hline $\begin{array}{l}\text { Employees at all } \\
\text { level have a clear } \\
\text { understanding of } \\
\text { how ongoing } \\
\text { technology } \\
\text { changes directly } \\
\text { relate to or impact } \\
\text { our innovation } \\
\text { efforts. }\end{array}$ & .759 & & & .783 \\
\hline $\begin{array}{l}\text { When } \\
\text { communicating } \\
\text { with customers, } \\
\text { marketers should } \\
\text { focus largely on } \\
\text { risks and benefits }\end{array}$ & .587 & & & .825 \\
\hline $\begin{array}{l}\text { Factor } \\
\text { Transparency }\end{array}$ & .722 & $\begin{array}{l}1.6 \\
0\end{array}$ & $\begin{array}{l}4.16 \\
\%\end{array}$ & .638 \\
\hline $\begin{array}{l}\text { Your organization } \\
\text { provides } \\
\text { information about } \\
\text { product, } \\
\text { technologies and } \\
\text { business systems. }\end{array}$ & .722 & & & .809 \\
\hline $\begin{array}{l}\text { Transparency } \\
\text { attracts not only } \\
\text { customers but also } \\
\text { investors and } \\
\text { empowering many } \\
\text { of them to the } \\
\text { tourism industry. }\end{array}$ & .567 & & & .604 \\
\hline Co-innovation & .564 & & $\begin{array}{l}7.38 \\
\%\end{array}$ & .784 \\
\hline $\begin{array}{ll}\text { Factor } & 1: \\
\text { Creativity } & \end{array}$ & .523 & $\begin{array}{l}1.4 \\
9\end{array}$ & $\begin{array}{l}7.00 \\
\%\end{array}$ & .710 \\
\hline $\begin{array}{lr}\text { Your organization } \\
\text { develops new } \\
\text { tourism products } \\
\text { and services } & \text { from } \\
\text { the ideas } & \text { of } \\
\text { customers, } & \\
\text { employees } & \text { and } \\
\text { competitors. }\end{array}$ & .721 & & & .727 \\
\hline Your organization & .787 & & & .773 \\
\hline
\end{tabular}

\begin{tabular}{|c|c|c|c|c|}
\hline $\begin{array}{|lr|}\text { improving } & \text { the } \\
\text { utilization } & \text { of } \\
\text { existing } & \text { tourism } \\
\text { products } & \text { and } \\
\text { services } & \\
\end{array}$ & & & & \\
\hline $\begin{array}{lr}\text { Your organization } \\
\text { focus } \\
\text { identifying new } \\
\text { types of customers } \\
\text { and developing } \\
\text { products r and } \\
\text { services that will } \\
\text { appeal to existing } \\
\text { the r future } \\
\text { customers }\end{array}$ & .757 & & & .824 \\
\hline $\begin{array}{l}\text { Product and service } \\
\text { innovation is vital } \\
\text { for gaining and } \\
\text { sustaining } \\
\text { competitive } \\
\text { advantage. }\end{array}$ & .547 & & & .693 \\
\hline $\begin{array}{ll}\text { Factor } & 2: \\
\text { Collaboration } & \\
\end{array}$ & .527 & $\begin{array}{c}1.1 \\
3\end{array}$ & $\begin{array}{l}6.99 \\
\%\end{array}$ & .728 \\
\hline \begin{tabular}{lr}
\multicolumn{2}{|l}{ Your organization } \\
adopting & new \\
technology & to \\
leverage & its \\
resources rand & and \\
bridge relationships \\
to advance & its \\
collaboration & \\
efforts.
\end{tabular} & .792 & & & .765 \\
\hline $\begin{array}{l}\text { Advances in } \\
\text { information and } \\
\text { web technologies } \\
\text { have led to the } \\
\text { quick and easy } \\
\text { access of } \\
\text { information that } \\
\text { businesses can use } \\
\text { to identify market } \\
\text { opportunities }\end{array}$ & .754 & & & .788 \\
\hline $\begin{array}{l}\text { Technology } \\
\text { adoption has led to } \\
\text { significant } \\
\text { performance } \\
\text { improvements and } \\
\text { increased in } \\
\text { productivity }\end{array}$ & .507 & & & .845 \\
\hline Factor 3: control & .605 & $\begin{array}{c}1.0 \\
2\end{array}$ & $\begin{array}{c}7.38 \\
\%\end{array}$ & .709 \\
\hline \begin{tabular}{lr}
\multicolumn{2}{|c}{ Your organization } \\
has information \\
systems & or \\
operational & \\
capability & to \\
develop & \\
personalized & \\
experience & \\
\end{tabular} & .753 & & & .800 \\
\hline
\end{tabular}




\begin{tabular}{|c|c|c|}
\hline $\begin{array}{l}\text { environments to } \\
\text { meet the needs and } \\
\text { preferences } \\
\text { customers. }\end{array}$ & & \\
\hline $\begin{array}{l}\text { Customer } \\
\text { participation and } \\
\text { feedback during } \\
\text { their stay help the } \\
\text { organization } \\
\text { receives more } \\
\text { control over the } \\
\text { services quality. }\end{array}$ & .501 & .795 \\
\hline $\begin{array}{l}\text { Customer } \\
\text { participation and } \\
\text { feedback during } \\
\text { their stay help the } \\
\text { organization } \\
\text { receives less } \\
\text { service failure }\end{array}$ & .522 & .841 \\
\hline $\begin{array}{l}\text { Our organization } \\
\text { measures the } \\
\text { success of co- } \\
\text { created products } \\
\text { and services } \\
\text { improved } \\
\text { collaboration } \\
\text { among different } \\
\text { departments in the } \\
\text { organization. }\end{array}$ & .657 & .725 \\
\hline
\end{tabular}

\section{Discussion and Conclusion}

The aim of this study is to investigate the relationship between co-creation and coinnovation in the tourism and hospitality industry. From the results, it can be concluded that there is a significant relationship between co-creation and co-innovation process. In other words, co-creation has a direct positive impact on co-innovation. Customers and organizations collaborate and co-create to introduce innovative products and services. As co-creation, is improving new products and services in a fast, convenient and innovative way better than the traditional processes resulting from the continued interaction between the company and its customers and external stakeholders (Wandahl et al., 2011; Sawhney, 2006).

The findings also indicated that there is a positive significant relationship between employees' work experience and co-creation and co-innovation. This means that as work experience years of employees increase, their skills and abilities to co-create and co-innovate with their customers increase. Furthermore, factor analysis was used to identify the underlying dimensions, of the co-innovation and co-creation factors (32 items), using principal component analysis with orthogonal VARIMAX rotation. The results of the factor analysis revealed that factors are fairly higher loadings on suitable factors. Most variables loaded deeply on one factor and this indicated that there was minimum interrelation among factors and that all factors were independently ordered. The correlations of the variables were signaled the higher loadings with the factors on which they were loaded. In conclusion, it is evident that cooperation with customers, share information with them and consider their suggestions and ideas in the products and services they wanted become an important issue for any organization. As the market conditions have changed and customers' needs and preferences are in permanent change, the collaboration with guests in designing, producing and creating new products and services becomes a vital matter to create value for them and to succeed in producing innovative products and services. Consequently, Innovation through co-creation helps an organization to achieve competitive advantage via sharing of customers with the organization in designing and development of product and services (Reay and Seddighi, 2012; Haro et al., 2014). Therefore, cocreation becomes the cornerstone for the success of the innovation process. As a result, hotels and travel agents should be considered 
the importance of co-creation and coinnovation activities in order to achieve competitive advantage, succeed and sustain in the market.

\section{References}

- Aarikka-Stenroos, L. and Jaakkola, E. (2012). "Value co-creation in knowledge intensive business services: A dyadic perspective on the joint problem solving process", Industrial Marketing Management, 41 (1), 15-26.

- $\quad$ Adler, P., Heckscher, C. and Prusak, L. (2011). "Building a collaborative enterprise", Harvard Business Review, 89 (7/8), 94-101.

- Albinsson, A.P., Perera, Y. and Sautter, T.P. (2016). "DART scale development: Diagnosing a firm' $\mathrm{s}$ readiness for strategic value co-creation", Journal of Marketing Theory and Practice, 24 (1), 42-58.

- Amabile, T.M. (1997). "The motivation for creativity in organizations: On doing what you love and loving what you do", California Management Review, 40 (1), 39-58.

- $\quad$ Auh, S., Bell, S.J., Mcleod, C.S. and Shih, E. (2007), "Co-production and customer loyalty in financial services", Journal of the Academy of Marketing Science, 28 (1), 138-149.

- Ballantyne, D. (2004), "Dialog and its role in the development of relationship specific knowledge", Journal of Business and Industrial Marketing, 19 (2), 114-123.

- Bitner, M.J., Brown, S.W. and Meuter, M.L. (2000), "Technology infusion in service encounters", Journal of the Academy of Marketing Science, 28 (1), 138-149.

- Chen, J., Tsou, H. and Ching, R. (2011), "Coproduction and its effects on service innovation", Industrial Marketing Management, 40 (8), 1331-1346.

- Chen, J.C., Kerr, D., Chou, Y.C. and Ang, C. (2017), "Business co-creation for service innovation in the hospitality and tourism industry", International Journal of Contemporary Hospitality Management, 29(6), 1522-1540.

- Chesbrough, H. (2003). Open Innovation: The New Imperative for Creating and Profiting from Technology, Harvard Business School Press, Boston, MA.

- Clathoth, P., Altinay, L., Harrington, R.J., Okumus, F. and Chan, E.S. (2013). "Co- production versus co-creation: A process based continuum in the hotel service context", International Journal of Hospitality Management, 32, 11-20.

- Della Corte, V., Savastano, I. and Storlazzi, A. (2009). "Service innovation in cultural heritages management and valorization", International Journal of Quality and Service Sciences, 1(3), 225-240.

- Edvardsson, B., Tronvoll, B., and Gruber, T. (2011). "Expanding understanding of service exchange and value co-creation: A social construction approach", Journal of the Academy of Marketing Science, 39, 327-339.

- Ehlen, C., Klink, M. Stoffers, J. and Boshuizem, H. (2017). "The co-creationwheel: A four dimensional model of collaborative, interorganizational innovation", European Journal of Training and Development, 41 (7), 628-646.

- Fu, X. and Lehto, X. (2018). "Value cocreation: The case of Chinese family travelers", International Journal of Contemporary Hospitality Management, 30 (2) 980-1000.

- Fuller, J., Mühlbacher, H., Matzler, K. and Jawecki, G. (2009), "Consumer empowerment through internet-based co-creation", Journal of Management Information Systems, 26 (3), 71102.

- Grissemann, U.S. and Stokburger-Sauer, N.E. (2012). "Customer co-creation of travel services: The role of company support and customer satisfaction with the co-creation performance", Tourism Management, 33 (6), 1483-1492.

- Grönroos, C. and Voima, P. (2013). "Critical service logic: Making sense of value creation and co-creation", Journal of the Academy of Marketing Science, 41 (2), 133-150.

- Gulati, R., Nohria, N. and Zaheer, A. (2000). "Strategic networks", Strategic Management Journal, 21, (Special Issue), 203- 215.

- Gupta, A. and Govindarajan, V. (2003), Global Strategy and the Organization, Wiley, New York, NY.

- Hagel, J. III and Armstrong, A.G. (1997). Net Gain: Expanding Markets through Virtual Communities, Harvard Business School Press, Boston, MA.

- Hall, C.M., \& Williams, A.M. (2008). Tourism and Innovation. London: Routledge. 
- Hamidi, F. and Gharneh, S.N. (2017). "Impact of co-creation on innovation capability and firm performance: A structural equation modeling", AD-Minister, 30, 73-90.

- Haro, A.M., Ruiz, P.M. and Canas, M.R. (2014). "The effects of value co-creation process on the consumer and the company", Expert Journal of Marketing, 2, 68-81.

- Helms, R. W., Booij, E., \& Spruit, M. R. (2012). "Reaching out: Involving users in innovation tasks through social media", ECIS 2012 Proceedings, Paper 193.

- Hjalager, A.M. (2010), "A Review of Innovation Research in Tourism", Tourism Management, 31(1), 1-12.

- Hoyer, W.D., Chandy, R., Dorotic, M., Krafft, M. and Singh, S.S. (2010), "Consumer cocreation in new product development", Journal of Service Research, 13 (3), 283-296.

- Ind, N., \& Coates, N. (2013), "The meanings of co-creation", European Business Review, 25(1), 86-95.

- Jernsand, E.M. (2017). "Innovation as a Vital Part of Place Branding", Paper presented at the Encuentros/AIRTH 2017, March 23-25 Conference, Portorož, Slovenia.

- Johannessen, J.A., Olsen, B. and Luumpkin, G.T. (2001). "Innovation as newness: What is new, how new and new to whom?", European Journal of Innovation Management, 4 (1), 20 31.

- Johnson, G. and Neuhofer, B. (2017). "Airbnban exploration of value co-creation experiences in Jamaica", International Journal of contemporary Hospitality Management, 29 (9), 2361-2376.

- Joshi, A.W. \& Sharma, S. (2004). "Customer knowledge development: Antecedents and impact on new product performance", Journal of Marketing, 68(1), 47-59.

- Kirah, A. (2009). "Co-creation: A New Way of Doing Business in an Age of Uncertainty", Open Source Business Resource, 29-32.

- $\quad$ Kumar, V. and Petersen, J.A. (2013). "Using a Customer-Level Marketing Strategy to Enhance Firm Performance: A Review of Theoretical and Empirical Evidence", Journal of the Academy of Marketing Science, 33(4), 504-519.

- Lee, M.S., Olson, L.D. and Trimi, S. (2012)."Co-innovation: Convergenomics, collaboration and co-creation for organizational values", Management Decision, 50 (5), 817-831.

- Lewis, D., \& Bridger, D. (2001). The soul of the new consumer. London: Nicholas Brealey Publishing.

- $\quad$ Lusch, R., Vargo, S. and Wessels, G. (2008). "Toward a conceptual foundation for service science: Contributions from service-dominant logic", IBM Systems Journal, 47 (1), 8-10.

- Magnusson, P.R., Matthing, J. \& Kristensson, P. (2003). "Managing user involvement in service innovation: Experiments with innovating end users". Journal of Service Research, 6(2), 111-124.

- Maklan, S., Knox, S. and Ryals, L. (2008). "New trends in innovation and customer relationship management", International Journal of Market Research, 50(2), 221-240.

- Nambisan, P. and Nambisan, S. (2009). "Models of consumer value co-creation in healthcare", Healthcare Management Review, 34 (4), 344-354.

- Nicolajsen, H. W., \& Scupola, A. (2011). "Investigating issues and challenges for customer involvement in business services innovation", Journal of Business \& Industrial Marketing, 26(5), 368-376.

- Nicolau, JL. And Santa-Maria, M.J. (2013). "The effect of innovation on hotel market value", International Journal of Hospitality Management, 32, 71-79.

- Nieves, J. and Segarra-Ciprés, M. (2015). "Management innovation in the hotel industry", Tourism Management, 46, 51-58.

- Noursis, M. J. (1994). SPSS professional statistics 6.1. Chicago, IL: SPSS, Inc.

- Nunnally, J. C. (1978). Psychometric theory $\left(2^{\text {nd }}\right.$ ed. $)$, New York, NY: McGraw-Hill.

- O'cass, A. and Sok, P. (2013). "Exploring innovation driven value creation in B2B service firms: The roles of the manager, employees and customers in value creation", Journal of Business Research, 66(8), 10741084.

- Ottenbacher, M., Gnoth, J. and Jones, P. (2006). "Identifying determinants of success development of new high-contact services: Insights from the hospitality industry", International of Service Industry Management, 17 (4), 344-363. 
- Payne, A.F., Storbacka, K. and Frow, P. (2008), "Managing the co-creation of value", Journal of the Academy of Marketing Science, 36 (1), 83-96.

- Pikkemaat, B. and Zehrer, A. (2016). "Innovation and service experiences in small tourism family firms", International Journal of Culture, Tourism and Hospitality Research, 10 (4), 343-360.

- Piller, F., Ihl, C., \& Vossen, A. (2010). "A typology of customer co-creation in the innovation process", Chapter in SSRN Electronic Journal Retrieved from http://tim.rwth-aachen.de/piller.

- $\quad$ Pitt, L. F., \& Jeantrout, B. (1994). Management of customer expectations in service firms: A study and a checklist. The Service Industries Journal, 14(2), 170-189.

- Prahalad, C.K. and Ramaswamy, V. (2004a). "Co-creation experiences: The next practice in value creation", Journal of Interactive Marketing, 18, 5-14.

- Prahalad, C.K. and Ramaswamy, V. (2004b), "The Future of Competition: Co-creating Unique Value with Customers", Harvard Business School Press, Boston, MA.

- Prahalad, C.K. \& Ramaswamy, V. (2004c). The Future of Competition: Co-Creating Unique Value with Customers. Harvard Business School Press. Boston, MA.

- Prahalad, C.K. and Krishnan, M.S. (2008). The new age of innovation: Driving co-created value through global network, McGraw-Hill, New York.

- Ramaswamy, V. and Gouillart, F. (2010). The Power of Co-creation, The Free Press, New York, NY.

- Reay, P. and Seddighi, R. H. (2012). "An empirical evaluation of management and operational capabilities for innovation via cocreation", European Journal of Innovation Management, 15 (2), 259-275

- Rheingold, H. (2000). The Virtual Community: Homesteading on the Electronic Frontier, MIT Press, Cambridge, MA.

- Rigolizzo, M., \& Amabile, T. (2015). "Entrepreneurial creativity: The role of learning, processes and work environment supports", The Oxford handbook of creativity, Innovation and Entrepreneurship, Oxford university press, New York.
- $\quad$ Russo-Spena, T., \& Mele, C. (2012). "Five Co$\mathrm{s}$ " in innovating: A practice-based view", Journal of Service Management, 23(4), 527553.

- Saarijarvi, H., \& Kannan, P.K. (2013). Value co-creation: Theoretical approaches and practical implications", European Business Review, 1, 6-19.

- $\quad$ Sahi, K.C., Sehgal, S. and Sharma, R. (2017). "Predicting customers recommendation from co-creation of value, customization and relational value", The Journal for Decision Makers, 42 (1), 19-35.

- Sang M. Lee, David L. Olson, Silvana Trimi, (2012) "Co-innovation: convergenomics, collaboration, and cocreation for organizational values", Management Decision, 50 (5), 817831.

- Sarmah, B., Kamboj, S. and Rahman, Z. (2017). "Co-creation in hotel service innovation using smart phone apps: An empirical study", International Journal of Contemporary Hospitality Management, 29 (10), 2647-2667.

- Sarmah, B., Rahman, Z. and Kamboj, S. (2017). "Customer co-creation and adoption intention towards newly developed services: An empirical study", International Journal of Culture, Tourism and Hospitality Research, 11 (3), 372-391.

- Sawhney, M. (2006). Going beyond the product: Defining, designing, and delivering customer solutions. in Vargo, S.L. and Lusch, R.F. (Eds), The service-dominant Logic of Marketing: Dialog, Debate, and Directions, M.E. Sharp, Armonk, NY.

- Shaw, G., Bailey, A. and Williams, A. (2011). "Aspects of service-dominant logic and its implications for tourism management: Examples from the hotel industry", Tourism Management, 32 (2), 207-214.

- Sjodin, C., Kristensson, K. (2012). "Customers' experiences of co-creation during service innovation", International Journal of Quality and Service Sciences, 2, 189-204.

- Skiba, F., \& Herstatt, C. (2009). "Users as sources for radical service innovations: Opportunities from collaboration with service lead users", International Journal of Services Technology and Management, 12, 317-337. 
- $\quad$ Tang, W.T., Wang, C.M. and Tang, Y. (2015). "Developing service innovation capability in the hotel industry", Service Business: An international Journal, 9 (1), 97-113.

- Tijmes, A.H. (2010). Co-creation and firm performance: Innovation success enhancing effects of and motives for customer involvement. Msc. In business administration, specialization track in innovation and Entrepreneurship, University of Twent, the Netherland.

- Toivonen, M., Touminen, T., \& Brax, S. (2007). Innovation Process Interlinked with the Process of Service Delivery: A Management Challenge in KIBS. Économies et Sociétés, 8(3), 355-384.

- Toivonen, M. and Touminen, T. (2009). "Emergence of innovations in services", The Services Industries Journal, 9 (7), 887-902.

- Vandenbosch, M. and Dawar, N. (2002). "Beyond better products: capturing value in customer interactions", MIT Sloan Management Review, 43 (4), 35-42.

- $\quad$ Vargo, S.L., and Lusch, R.F. (2004) "Evolving to a New Dominant Logic for Marketing", Journal of Marketing, 68, 1 - 17.

- Von Hippel, E. (2001). "Innovation by user communities: Learning from open-source software", MT Sloan Management Review, 42 (4), 82.

- Von Hippel, E. (2005). "Democratizing innovation: The evolving phenomenon of user innovation", MIT Sloan School of Management, 55, 63-78.

- Von Hippel, E., Ozawa, S. and De Jong, J. (2011), "The age of the consumer-innovator", MIT Sloan Management Review, Fall, 27-35.
- Wandahl, S., Jacobsen, A., Lassen, A. H., Poulsen, S. B., Denmark, A., \& Sørensen, H. (2011). "User-driven innovation in a construction material supply network", Construction Innovation, 11(4), 399-415.

- Williams, A.M. and Shaw, G. (2011). "Internationalization and innovation in tourism”, Annals of Tourism Research, 38 (1), 27-51.

- Wind, Y.J. \& Rangaswamy, A. (2001). "Customization: The next revolution in mass customization", Journal of interactive marketing, 15 (1), 13-32.

- Windham, L., \& Orton, K. (2001). The soul of the new consumer. New York, NY: Allworth.

- Zhang, X. and Chen, R. (2008). "Examining the mechanism of the value co-creation with customers", International Journal of Production Economics", 16, 242-250.

\section{• ملخص البحث باللغة العربية \\ دراسة العلاقة بين الإبداع المشترك ونجاح الإبتكار في صناعة السياحة والفنادق}

يهدف هذا البحث لدراسة العلاقة بين الإبداع المشترك ونجاح الإبتكار في صناعة السياحة والفنادق. كما يدرس تأثير خبرة

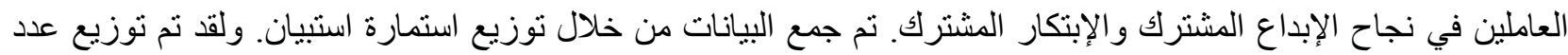
420 استمارة استبيان على موظفي الفنادق وشركات السياحة بمحافظتي الإسكندرية والقاهرة حيث تم استرداد عدد 398 استمارة

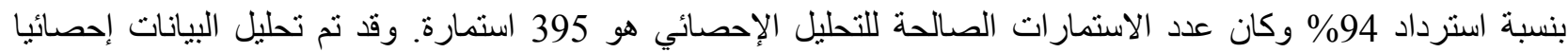

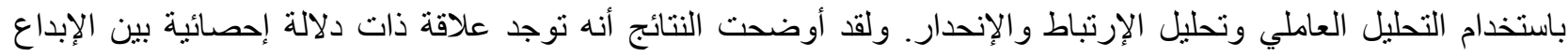
المشترك و الإبتكار المشترك. بالإضافة لذلك فقد أظهرت النتائج الى وجود ارتباط التاط مغزوي بين عدد سنوات خبرة العاملين ونجاح الإبداع المشترك والإنبتكار المشترك. 